\title{
Two varieties of Clerodendrum $L$. (Lamiaceae) from Madagascar raised to specific rank
}

\author{
Peter B. Phillipson \& Martin W. Callmander
}

\begin{abstract}
PHILLIPSON, P.B. \& M.W. CALLMANDER (2016). Two varieties of Clerodendrum L. (Lamiaceae) from Madagascar raised to specific rank. Candollea 71: 373-377. In English, English and French abstracts. DOI: http://dx.doi.org/10.15553/c2016v712a19

The authors raise two varieties of Clerodendrum aucubifolium Baker to species rank, providing the new combination Clerodendrum giganteum (Moldenke) Phillipson \& Callm. for one, and the replacement name Clerodendrum thouarsii Phillipson \& Callm. for the other. The two species differ from typical Clerodendrum aucubifolium and other related species by their distinctive inflorescence structure and floral morphology, and from each other primarily by differences in leaf and bract shape and size.
\end{abstract}

\section{Résumé}

PHILLIPSON, P.B. \& M.W. CALLMANDER (2016). Deux variétés de Clerodendrum L. (Lamiaceae) de Madagascar élevés au rang d'espèce. Candollea 71: 373-377. En anglais, résumés français et anglais. DOI: http://dx.doi.org/10.15553/c2016v712a19

Les auteurs élèvent deux variétés de Clerodendrum aucubifolium Baker au rang d'espèce, proposant pour l'une la nouvelle combinaison Clerodendrum giganteum (Moldenke) Phillipson \& Callm., et pour l'autre le nom de remplacement Clerodendrum thouarsii Phillipson \& Callm. Les deux espèces diffèrent du Clerodendrum aucubifolium typique et des espèces apparentées par une structure distincte de l'inflorescence et de la morphologie florale et entre elles principalement par les différences de forme et de taille des feuilles et des bractées.

\section{Keywords}

LAMIACEAE - Clerodendrum - Nomenclature - Madagascar

\footnotetext{
Addresses of the authors:
}

PBP: Missouri Botanical Garden, P.O. Box 299, St. Louis, MO, 63166-0299, U.S.A. and Institut de Systématique, Evolution, et Biodiversité (UMR 7205 - CNRS MNHN EPHE UPMC), Muséum national d'Histoire naturelle, C.P. 39, rue Cuvier 57, 75231 Paris CEDEX 05, France. E-mail: peter.phillipson@mobot.org MWC: Conservatoire et Jardin botaniques de la Ville de Genève, C.P. 60, 1292 Chambésy, Switzerland. 


\section{Introduction}

The genus Clerodendrum L. (Lamiaceae) as currently circumscribed comprises approximately 300 species, mostly native to Asia, Africa and Madagascar (Plant List, 2016), and occuring primarily in humid or subhumid forest habitats within the tropical zone. The genus was revised for Madagascar by Harold Moldenke, his work culminating in a Flora treatment (Moldenke, 1956). Extensive inventory work in Madagascar since that time has resulted in the accumulation of a considerable volume of new material, which has led to a few taxonomic novelties (see Phillipson \& Allorge, 2016 for an account of these), however much of the material has lacked critical study - a situation we are starting to remedy with the help of other collaborators. Our work has already resulted in a better understanding of many of the known species, providing for updated treatments in the Madagascar Catalogue (2016), as well as resulting in the identification of a number of new taxa that will be published in due course.

Clerodendrum aucubifolium Baker was described in 1894 based on two collections from Madagascar by Richard Baron. Moldenke (1956) associated this species with other species of the genus possessing long narrow corolla tubes. These include C. baronianum Oliv. and C. cauliflorum Vatke, which were discussed recently in an article describing the newly discovered C. kambyoae Phillipson \& L. Allorge (Phillipson \& Allorge, 2016), as well as the introduced C. indicum (L.) Kuntze and also two species that are now excluded from Clerodendrum and transferred to the genus Rotheca Raf. (CAllmander \& PhiLLIPSON, 2012) : Clerodendrum incisum Klozsch (as Rotheca microphylla (Blume) Callm. \& Phillipson) and Clerodendrum mirabilis Baker ( $=$ Rotheca mirabilis (Baker) Callm. \& Phillipson). This association of species is clearly artificial, placing together species with different fruit and calyx types - characters that are taken to be of phylogenetic importance in Clerodendrum and its allies (YuAn et al., 2010). However, Clerodendrum aucubifolium shares a number of morphological features with a group of five other species: four of which have relatively short corolla tubes $(C$. alboviolaceum Moldenke, C. eucalycinum Oliv., C. magnoliifolium Baker and C. rubellum Baker) and C. brunnescens Moldenke, whose corolla was unknown to Moldenke but which is now known to have long narrow corolla tube (Phillipson, unpubl. data). Like C. aucubifolium, these species are all well-branched shrubs or small trees, characterised by a combination of a terminal cymose panicle; a robust tubular coriaceous calyx that dries almost black (dark grey or dark brown) in herbarium material; a corolla with a narrow tube and widely flaring lobes forming a trumpet-shaped mouth, which is white with purple markings in the throat and tube. These plants apparently form a morphologically closely-related group of taxa.

Moldenke $(1950,1956)$ recognized three varieties within C. aucubifolium, describing C. aucubifolium var. giganteum Moldenke and C. aucubifolium var. longiflorum Moldenke as new - each based on a single collection. The new varieties were distinguished from the typical variety of $C$. aucubifolium, for which Moldenke only knew the two syntypes, by their much larger flowers - notably with respect to the length of the calyx and the corolla, and in the case of C. aucubifolium var. longiflorum by much larger leaves. His description of the two new varieties indicated the calyx and corolla of $C$. aucubifolium var. giganteum to be longer than those of $C$. aucubifolium var. longiflorum, and for the former variety to have a broader calyx but shorter corolla lobes than the latter.

Additional specimens are now available that correspond with these taxa and with the other related species mentioned above, and this has enabled us to reassess the variation in the group as a whole. In addition to the differences in flower size noted by Moldenke, his two newly described varieties differ from all other species in the group in having considerably more contracted inflorescences. In all of the other species mentioned above, as well as in typical C. aucubifolium, the panicle axis and branches are relatively slender, and the lateral branches constitute cymose units mostly bearing 3-5 flowers, whereas those of Moldenke's two new varieties have a very robust axis and the equally robust lateral units are almost always reduced to a single flower (except in one specimen, Antilabimena 2375, which has one inflorescence unit bearing two flowers). Corresponding with the large flowers and robust inflorescences, the bracts and bracteoles of Moldenke's two new varieties are also larger than those of other species in the group, particularly in the case of C. aucubifolium var. longiflorum. Clerodendrum brunnescens is the only other species of the C. aucubifolium group that has flowers approaching those of Moldenke's two varieties in size. It has a calyx $4.1-4.4 \mathrm{~cm}$ long, and a corolla tube (unknown to Moldenke) c. $10 \mathrm{~cm}$ long, with lobes $4.5-5 \mathrm{~cm}$ long. However its inflorescence is very lax with long pendulous lateral cymose units, quite unlike those of both of Moldenke's varieties. Leaf material of herbarium specimens of $C$. brunnescens tends to dry a rather uniform brown colour with conspicuous very dark brown veins, unlike the paler greygreen dried leaves with pale veins typical for the other species in the group.

Moldenke's two varieties are similar to each other in many respects, but they can easily be distinguished morphologically, and they occupy different distribution ranges, and we conclude that the two taxa merit recognition as distinct species. In this article we establish for them the new combination C. giganteum (Moldenke) Phillipson \& Callm. and the replacement name C. thouarsii Phillipson \& Callm., and we also lectotypify C. aucubifolium, providing the relevant nomenclatural details for each species, and a discussion of their diagnostic characters. We also provide information of their known occurrence in Madagascar and conservation assessments following IUCN Red List Categories and Criteria (IUCN, 2012). Additional data, images and distribution maps for these three 
species as well as the other taxa mentioned in this article are available in the Madagascar Catalogue (2016) and in the Sonnerat (2016) database.

\section{Taxonomy}

Clerodendrum aucubifolium Baker in Bull. Misc. Inform. Kew 87: 102. 1894.

Lectotypus (designated here) : Madagascar. Prov. Antsiranana: "North Madagascar", 1891, Baron 6408 (K [K000192962]!; isolecto-: NY [NY00137322] image seen, P [P00440395]!). Syntypus: MadagasCar. Prov. Antsiranana: "North Madagascar", 1891, Baron 6151 (K [K000192961]!).

Distribution, ecology and conservation status. - Clerodendrum aucubifolium appears to be relatively rare, having been collected only infrequently, even in areas where inventory work has been conducted. It is known with certainty from three localities within the subhumid bioclimatic zone in the northern part of Madagascar, notably in the protected areas of AmpasindavaGaloka-Kalobinono and Manongarivo. Precise localities for four older collections cannot be determined. Available information indicates that the species occurs in dense humid forest including degraded clearings, and on rocky outcrops, at elevations between 150 and $800 \mathrm{~m}$, and flowering has been documented between the months of May and October. The three known precise locations represent three separate subpopulations, each of which falls within a protected area, none of which are known to be threatened, and no decline in the extent of occurrence or area of occupancy of the species can be projected. Clerodendrum aucubifolium is therefore assessed as "Least Concern" [LC] following IUCN Red List Categories and Criteria (IUCN, 2012).
Observations. - Clerodendrum aucubifolium was based on two syntypes, both collected in "North Madagascar" (with no other locality information) by Richard Baron (1847-1907), who collected extensively in Madagascar between 1972 and 1907 while based in Antananarivo for the London Missionary Society. Apparently he made a 5-month tour of the north of the country in 1891 (DorR, 1997), and it is presumably at this time that the two collections were made. The two syntypes are very similar, both comprise flowering and vegetative material and the Kew sheets were both annotated "Type" by Baker. They clearly represent the same species, but we select Baron 6408 as the lectotype of C. aucubifolium, since it is known to be represented in at least three herbaria, while the other syntype, Baron 6151, is only known to be present at Kew. The differences between typical C. aucubifolium and the two varieties that we raise to species level in this article are discussed above and are summarised in Table 1 . The species can be generally distinguished from other species of the group by the combination of membranous, elliptic leaves up to c. $150 \mathrm{~mm}$ long; calyx c. $22 \times$ $7 \mathrm{~mm}$; corolla tube c. $45 \mathrm{~mm}$ long.

Other specimens examined. - Madagascar. Prov. Antsiranana: Ambanja, Ambobaka Fkt., forêt de Tsiandianatalata, 1344'11"S 4830'05”E, 345 m, 25.VIII.2002, Hong-Wa et al. 63 (MO, P, TAN, TEF); sur grès liasiques des env. du Sambirano, V.1909, Perrier de la Bâthie 10225 (P [2 sheets]); Ambilobe, Beramanja, Anketrabe Bilinta, village Ambahatra, forêt de Galoko, 133'3'"S 4842'34"E, 149 m, 7.X.2013, Randriatsivery et al. 461 (MO, P, TAN); Manongarivo, vallée de l'Ambahatra, cours moyen, Bemamboly (rive droite), 13¹4'30"S 49¹1'13”S, 415 m, 26.V.2001, Woblhauser et al. 441 (G, P, TAN, TEF). Prov. Mahajanga: Befandriana Nord, 800 m, 30.X.1942, Herb. Jard. Bot. Tana. 5302 (P,TAN).

Table 1. - Comparison of key characters that differentiate Clerodendrum aucubifolium Baker, C. giganteum (Moldenke) Phillipson \& Callm. and C. thouarsii Phillipson \& Callm.

\begin{tabular}{|c|c|c|c|}
\hline & C. aucubifolium & C. giganteum & C. thouarsii \\
\hline Leaf shape and texture & elliptic, membranous & $\begin{array}{l}\text { narrowly elliptic-obovate, } \\
\text { membranous }\end{array}$ & $\begin{array}{l}\text { broadly elliptic-obovate, } \\
\text { sub-coriaceous }\end{array}$ \\
\hline Largest leaf blade size [cm] & $12-15 \times(4.5-) 5.5-7$ & $13-18 \times 4.5-5.5$ & $13-27 \times 8-13$ \\
\hline Inflorescence structure & very lax & somewhat contracted & highly contracted \\
\hline Inflorescence units & 3-7-flowered & mostly 1-flowered & 1-flowered \\
\hline Bracts subtending inflorescence unit [mm] & c. $3 \times 3$ & c. $3 \times 3$ & $13-16 \times 8-10$ \\
\hline Bracts subtending flower [mm] & $3 \times 1(-2)$ & $7 \times 1$ & $15 \times 2$ \\
\hline Pedicels [mm] & $12-28 \times 0.75$ & $12-16 \times 1.5$ & $8-15(-25) \times 2.5$ \\
\hline Calyx dimensions at anthesis [mm] & C. $22 \times 7$ & c. $50 \times 10$ & $40-55 \times 9-12$ \\
\hline Ultimate length of corolla tubes [cm] & c. 4.5 & c. 18 & c. $14(-18.5)$ \\
\hline Diameter of corolla tube mouth & c. 10 & c. 18 & c. 17 \\
\hline Corolla lobes & $20 \times 9$ & c. $20 \times 13$ & c. $27 \times 18$ \\
\hline
\end{tabular}


Clerodendrum giganteum (Moldenke) Phillipson \& Callm., comb. et stat. nov.

$\equiv$ Clerodendrum aucubifolium var. giganteum Moldenke in Bull. Torrey Bot. Club 77: 393. 1950.

Typus: Madagascar. Prov. Antsiranana: Sambirano,

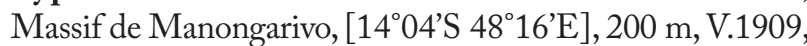
Perrier de la Bâthie 10229 (holo-: P [P00440396]!; iso-: P [P00440397, P00440398]!).

\section{Vernacular name. - "Ambora" (Antilabimena 2089).}

Distribution, ecology and conservation status. - Clerodendrum giganteum is known from five localities scattered across the northern part of Madagascar, spanning the humid and subhumid bioclimatic zones, and all within Madagascar's protected area network (Ampasindava-Galoka-Kalobinono, Makira, Manongarivo, and Marojejy). The species would appear to be relatively rare, having been collected few times despite having highly conspicuous flowers and generally occurring in areas where inventory work has been conducted. The collections have all been made in forest or woodland, frequently near streams, on a variety of substrates, at low elevations (near sea-level to $200 \mathrm{~m}$ ) in the west and mid to high elevations (900 to $1200 \mathrm{~m}$ ) in the east. The localities are taken to represent five separate subpopulations, none of which are known to be threatened, and no decline in the extent of occurrence or area of occupancy of the species can be projected. Clerodendrum giganteum is therefore assessed as "Least Concern" [LC] following IUCN Red List Categories and Criteria (IUCN, 2012).

Observations. - Clerodendrum giganteum was distinguished by Moldenke (1950: 393) from typical C. aucubifolium by its much larger calyx - " $4.5-5 \mathrm{~cm}$ long, flaring to $2.5 \mathrm{~cm}$ wide at the apex" at anthesis, and by its slender corolla tube - "up to $18 \mathrm{~cm}$ long", expanding to a funnelshaped mouth, with its lobes c. $2 \mathrm{~cm}$ long, and a deeply lobed fruiting-calyx. The species is not known to have been collected again at the type locality (the Manongarivo Massif in north-western Madagascar), but the type can be matched with material from a number of other sites in the north of the island. The exceptionally large size of the calyx and corolla of this plant is confirmed by our study, but the stated diameter of the calyx apex was mis-reported, all of the flowers on the type collection have a calyx diameter of no more than c. $10 \mathrm{~mm}$. The mouth of the corolla is considerably larger in diameter, and it is possibly this dimension that was given in error. Careful examination of the holotype and two isotypes at $\mathrm{P}$, reveal considerable variation in the length of the corolla tube, and some of the open flowers of these specimens are only c. $8 \mathrm{~cm}$ long. This trend is seen in other specimens of C. giganteum, and we hypothesise that the corolla tube, the filaments and style might continue to expand during anthesis. Perhaps an adaptation of this kind could facilitate pollination by a range of different pollinators, but clearly field observations are needed to confirm or refute this hypothesis. Otherwise, calyx and corolla dimensions vary little among the other specimens now available. Clerodendrum giganteum can be distinguished from C. thouarsii by its smaller $(13-18 \times 4.5-5.5$ vs. $13-27 \times$ $8-13 \mathrm{~cm}$ ) leaves which are narrowly elliptic-obovate and membranous vs. broadly elliptic-obovate and sub-coriaceous, and also by its less contracted inflorescences with much smaller bracts (the bract subtending the inflorescence unit $3 \times 3 \mathrm{~mm}$ vs. $13-16 \times 8-10 \mathrm{~mm}$, and the bract subtending the flower $7 \times 1 \mathrm{~mm}$ vs. $15 \times 2 \mathrm{~mm}$ ). The corollas of C. giganteum generally have longer tubes, but shorter lob es than those of $C$. thouarsii. See Table 1 for more details of the different between the two species.

Other specimens examined. - Madagascar. Prov. Antsiranana : partie occidentale du Massif de Marojejy (NE) de la vallée de l'Ambatoharanana au bassin supérieur de l'Antsahaberoka, 1000-1200 m, 9.XI-2.XII.1959, Humbert \& Saboureau 31407 (P); Bemanevika, affluent de la riv., péninsule d'Ampasindava, 1346'03"S 4758'52"E, 34 m, 30.I.2009, Rakotovao 4339 (G, MO, P, TAN). Prov. Toamasina: Masoala NP, Ambohitsitondroina Mahalevona, 15 26'07”S 49 57'27”E, 1172 m, 4.X.2003, Antilabimena 2089 (MO, P, TAN); Sahatany, Andongona, Makira, Bevory River, $15^{\circ} 27^{\prime} 55^{\prime \prime}$ S 49²0'10”E, 24.XI.2003, Antilabimena 2375 (MO, P, TAN).

\section{Clerodendrum thouarsii Phillipson \& Callm., nom. nov.}

$\equiv$ Clerodendrum aucubifolium var. longiflorum Moldenke in Bull. Torrey Bot. Club 77: 393.1950 [non C. longiflorum Decne.].

Typus: Madagascar. Prov. Toamasina: sine loc., s.d., $d u$ Petit Thouars s.n. (holo- : P [P00440399]!).

Etymology. - Clerodendrum thouarsii is named in honour of Louis Marie Aubert du Petit Thouars (1758-1831), who spent six months in Madagascar between July 1795 and January 1796 (Allorge \& IKor, 2012). He collected mainly along the east coast around Toamasina where he probably collected the type specimen of this species and annoted on his collection the name: "Volkameria longiflora P.", but this name has never been validely published. Du Petit-Thouars (1806) described many genera in Madagascar, and also several species, notably orchids (DU Petit-Thouars, 1822).

Vernacular names. - "Antambe" (Service Forestier 8603); "Ramidongana” (Service Forestier 26260); "Ravinatamba"(Réserves Naturelles 6661); "Antafana” (Réserves Naturelles 12125). 
Distribution, ecology and conservation status. - Clerodendrum thouarsii is known from humid forest from eight localities, on the eastern escarpment of Madagascar in a restricted area between Betampona and Fenoarivo near the east coast, and inland towards Lac Alaotra. Four of the collection localities fall within the protected area network (Betampona and Zahamena), but others lie outside. Therefore, with an extent of occurrence (EOO) of $<20,000 \mathrm{~km}^{2}$ and a projected continuing decline of lowland evergreen primary forest outside the protected area network, C. thouarsii can be assigned a preliminary risk of extinction of "Vulnerable" [VU B1ab(i,iii,iv,v)] following IUCN Red List Categories and Criteria (IUCN, 2012).

Observations. - MoldenKe (1950) did not provide a direct comparison between this plant and his var. giganteum, distinguishing it from typical C. aucubifolium by its larger coriaceous leaves borne on very stout petioles, by its long broad calyx and by long slender corolla tube and large corolla. Further differences between the three species are discussed in detail above, and summarized in Table 1. A new combination at species level based the varietal name "longiflorum" cannot be established since the name $C$. longiflorum Decne. already exists as a valid name for a species occuring in South-East Asia and Australia.

Other specimens examined. - Madagascar. Prov. Toamasina: Vavatenina, Sahatavy, Sahalangina, $17^{\circ} 27^{\prime} 04^{\prime \prime}$ S 48 $57^{\circ} 17^{\prime}$ E, 450 m, 24.X.2000, Andrianjafy E' Andriamiarisoa 114 (MO, P,TAN, TEF); Betampona NP, $17^{\circ} 55^{\prime} \mathrm{S} 49^{\circ} 13^{\prime} \mathrm{E}$, 300-400 m, 5.X.1994, Andrianarisata et al. 213 (MO, P, TAN); Ambalahady, Vavatenina, [17²8'36”S 49¹1'25”E], 100 m, 4.X.1940, Cours 1540 (P); Betampona NP, 250 m, 17 $7^{\circ} 55^{\prime}$ S 49 13'E, 3.X.2000, Iambana \& Fidel 291 (P); env. de Fénérive. [17 22'S 49²1'E], c. $100 \mathrm{~m}$, Perrier de la Bâthie 10197 (P [2 sheets]); Vavatenina, Ambodimangavalo, Manakambahiny I, près du PN de Zahamena, 17 34'S 48 57’'E, 18.X.2000, Ratovoson 291 (CNARP, MO, P, TEF); Betampona NP, [17 $55^{\prime} \mathrm{S} 49^{\circ} 13^{\prime} \mathrm{E}$ ], [300-550 m], 4.XI.1953, Service Forestier 8603 (P [2 sheets]); Vavatenina, Antananolobe, [17 $27^{\circ} \mathrm{S} 49^{\circ} 00^{\prime} \mathrm{E}$ ], 13.X.1966, Service Forestier 26260 (P, TEF); Betampona NP, 4.X.1954, Réserves Naturelles 6661 (P); ibid. loc.,12.VII.1958, Réserves Naturelles 9734 (P); Zahamena AP, 28.VI.1962, Réserves Naturelles 12125 (P). SINE LOC.: s.d., Lastelle s.n. (P).

\section{Acknowledgments}

The authors are grateful to the curators of the cited herbaria for the opportunity to study relevant specimens. We are also grateful to Laurent Gautier $(G)$ for his comments on an earlier draft of this note which has resulted in significant improvements.

\section{References}

Allorge, L. \& O. Iкоr (2003). La fabuleuse odysée des plantes. JC. Lattès.

Callmander, M.W., P.B. Phillipson, J.A. Wearn \& R.P.J. de KoK (2013). Adieu Adelosa Blume (Lamiaceae): Further observations on Rotheca Raf. for Madagascar. Candollea 68:316-320. DOI : http ://dx.doi.org/10.15553/c2012v682a18

Dorr, L.J. (1997). Plant Collectors in Madagascar and the Comoro Islands. Royal Botanic Gardens, Kew.

Du Petit-Thouars, L.M.A. (1806). Genera nova madagascariensia, secundum methodum Jussiaenam disposita. Paris.

Du Petit-Thouars, L.M.A. (1822). Histoire particulière des plantes Orchidées recueillies sur les trois îles australes d'Afrique, de France, de Bourbon et de Madagascar. Paris.

IUCN (2012). IUCN Red List Categories and Criteria: Version 3.1. $2^{\text {nd }}$ ed. Gland \& Cambridge.

Madagascar Catalogue (2016). Catalogue of the Vascular Plants of Madagascar. Missouri Botanical Garden, Antananarivo \& St. Louis [http://www.efloras.org/madagascar].

Moldenke, H.N. (1950). Novelties in the Eriocaulaceae and Verbenaceae, II. Bull. Torrey Bot. Club 77: 380-405.

Moldenke, H.N. (1956). Verbénacées. In: Humbert, H. (ed), Fl. Madagascar Comores 174.

Plant List (2016). Version 1.1. [http://www.theplantlist.org].

Phillipson, P.B. \& L. Allorge (2016). A remarkable new species of Clerodendrum L. (Lamiaceae) from Madagascar. Candollea 71: 117-126. DOI : http://dx.doi.org/10.15553/c2016v711a14

Sonnerat (2016). Base de données des collections du Muséum national d'Histoire naturelle. MNHN, Paris [http://science.mnhn.fr/ institution/mnhn/collection/p/item/search/form].

Yuan, Y.-W., D.J. Mabberley, D.A. Steane \& R.G. Olmstead (2010). Further disintegration and redefinition of Clerodendrum (Lamiaceae): implications for the understanding of the evolution of an intriguing breeding strategy. Taxon 59: 125-133. 